\title{
Microstructure, Mechanical Properties, Toughness, Wear Characteristics and Fracture Phenomena of Austenitised and Austempered Low-Alloyed Ductile Iron
}

\author{
Nabil Fatahalla ${ }^{*}$, Osama Hussein ${ }^{2}$ \\ ${ }^{1}$ Mechanical Department, Faculty of Engineering, Al Azhar University, Cairo, Egypt \\ ${ }^{2}$ El Nasr Castings Company, Tanash, Embaba, Giza, Egypt \\ Email: ${ }^{*}$ nfatahalla@tedata.net.eg
}

Received 11 January 2015; accepted 26 January 2015; published 30 January 2015

Copyright (C) 2015 by authors and OALib.

This work is licensed under the Creative Commons Attribution International License (CC BY). http://creativecommons.org/licenses/by/4.0/

(c) (i) Open Access

\begin{abstract}
Conventional ductile iron (DI) and austempered ductile iron (ADI) alloys were successfully produced. The alloying elements- $\mathrm{Ni}, \mathrm{Mo}, \mathrm{Cr}$ and $\mathrm{Mn}$ were added to get as-cast low-alloyed ductile iron (LADI) followed by austempering heat treatment. Hardness was measured for all investigated alloys. A hardness conversion table was deduced for irons investigated. Highest values of calculated quality index (QI) were for ADI alloys implying higher material performance. Impact energy values were attributed to microstructure and tensile properties. Wear characteristics of selected ADI alloys showed comparable values with LADI. Micro-hardness values were used to identify the micro-constituents and the work-hardened layers. Fracture modes were revealed and fracture surface observations were done by SEM. Due to higher toughness and QI, and cheap price, it is suggested that rolling mills may be produced from ADI, specially heat-treated instead of LADI.
\end{abstract}

\section{Keywords}

Austempered Ductile Iron, Low-Alloyed Ductile Iron, Tensile Properties, Wear Characteristics, Microstructure, Hardness

Subject Areas: Composite Material, Fundamentals of Material Science

\section{Introduction}

Ductile irons, having a spheroidal graphite structure, have been evolving during the last few decades [1], result-

"Corresponding author.

How to cite this paper: Fatahalla, N. and Hussein, O. (2015) Microstructure, Mechanical Properties, Toughness, Wear Characteristics and Fracture Phenomena of Austenitised and Austempered Low-Alloyed Ductile Iron. Open Access Library Journal, 2: e1012. http://dx.doi.org/10.4236/oalib.1101012 
ing in better combinations of mechanical strength and toughness. A further and recent advance [2] has been the introduction of austempering thermal treatment. The term of austempered ductile iron (ADI) describes a range of irons which have been subjected to an isothermal (specific austempering) heat treatment to produce an essentially bainitic structure in the material [3]. ADI has been one of the most significant developments in cast iron technology since the discovery of ductile iron [4]. Austempering has created a new family of irons with moderate level of toughness and ductility [4]. ADI is currently used widely in the place of cast, forged or low-alloyed steel, and weld components in a number of applications [1]. The commercial use of ADI is increasing continuously nowadays because their mechanical properties can be optimised and thereby enable the grades of standard ASTM A 897-M: 1990 (metric) to be satisfied [5]. However widespread use of this material cannot take place before the effect of composition, as-cast structure and heat-treated alloys are firmly established. Conventional ADI is two types-being alloyed and heat-treated DI [6]. The remarkable combination of strength and ductility has been attributed to differences in the type and amount of micro-constituents arising from variations of composition and austempering processing parameters [7]. The effect of some alloying elements on the microstructure and properties of austenitic ductile iron have been previously clarified by Fatahalla et al. [8]. The alloying elements such as nickel (Ni), molybdenum (Mo), chromium (Cr) etc. affect the mechanical properties of ADI [9].

The aim of the present investigation was to imply the examination of the influence of microstructure on the tensile properties, wear, fracture characteristics, and impact and fracture toughness for LADI and ADI. Another aim was to detect the possibility of using a specially heat-treated ADI to replace the low-alloyed steel or low-alloyed ductile.

\section{Experimental Procedures}

\subsection{Materials and Melting}

The materials investigated were produced in a normal production process of El Nasr Castings Co. in Egypt; Fatahalla et al. [10]. Pig iron, commercially pure iron and other alloys were melted in a basic high frequency induction furnace with a melt capacity of 6 ton/hr. The normal charge material, which produced conventional DI, was subjected to two austempering treatments, which produced ADI. Additions of the following alloys: FeNi (95\% $\mathrm{Ni})$, FeMo (70\% Mo), FeCr (70\% Cr), and FeMn (70\% Mn) were done to obtain LADI in the as-cast condition while the main addition alloy was the Nickel which was controlled at a level of 2 mass \%. The melt was then superheated and held at $1773 \mathrm{~K}$ for $0.6 \mathrm{ks}$. It was then tapped into a preheated ladle at $1733 \mathrm{~K}$ with a pocket in the base (Sandwich Technique) [10]. It was then inoculated (16\% by weight of charge) using Fe-Si-Mg alloy (45, 50 and 5 mass \% respectively) having a grain size of $15-50 \mathrm{~mm}$. thereafter, inoculated $(0.6 \%$ by weight of charge) using Fe-Si alloy ( $80 \% \mathrm{Si}$ ) having a grain size of $0.2-3 \mathrm{~mm}$. The inoculant was added to the stream of molten iron as the ladle was being filled for a period of $0.3 \mathrm{ks}$. The temperature of molten iron before treatment was measured to be $1693 \mathrm{~K}$ and after treatment was $1663 \mathrm{~K}$ for a period of $0.24 \mathrm{ks}$. An immersion thermocouple, digital meter stick was used to monitor the melt temperature in the induction furnace and pouring ladle. Spectrographic samples were cast in a copper mould for analysis by emission spectrograph. Table 1 shows the chemical compositions of the conventional DI and LADI.

\subsection{Casting Procedure}

After spheroidisation treatment, the melt was cast into a Y-block, using green sand moulds. All ingots of conventional DI and LADI, were cast into the same dimensions to maintain the same solidification cooling rate (SCR) and also the casting conditions. The conventional DI ingots were poured from a single preheated ladle at a pouring temperature in the range $1623-1643 \mathrm{~K}$ for $0.12 \mathrm{ks}$. The LADI was cast solely under almost the same conditions. Upon completion of pouring, all castings were allowed to cool overnight in the moulds before shake-

Table 1. Chemical composition of the conventional ductile-iron and LADI [mass \%].

\begin{tabular}{cccccccccccc}
\hline Elements & C & Si & S & P & Mn & Ni & Cr & Mo & Mg & CE \\
Materials & & & & & & & & & & \\
\hline Conventional ductile-iron & 3.57 & 2.20 & 0.013 & 0.036 & 0.086 & 0.02 & 0.02 & - & 0.040 & 4.315 \\
LADI & 3.50 & 1.54 & 0.009 & 0.045 & 0.71 & 2.22 & 0.75 & 0.45 & 0.042 & 4.100 \\
\hline
\end{tabular}


out and sandblasting.

\subsection{Sampling}

It is recommended [1] that most of machining be carried out before heat treatment, depending on the ADI components which will have either a high hardness or high work-hardening rate. The conventional DI Y-block samples were machined into specimens with $0.5 \mathrm{~mm}$ finishing allowance. The specimens were cut from the bottom of Y-blocks while the top sections were not used in order to avoid variations in nodule characteristics and porosity. After heat treating, the specimens were machined to final dimensions. The LADI castings got their dimensions by sectioning and grinding in cold working operations.

\subsection{Heat Treatments}

\subsubsection{Austempering Treatment}

The austempering treatment was performed in a specialised commercial heat treatment shop in the Iron and Steel Company in Egypt. The machined conventional DI and LADI specimens were placed in baskets, which were loaded one at a time into a high-temperature furnace for austenitisation. Following that, the baskets were transferred rapidly into a quenching medium (salt bath) held at the required austempering temperatures. Previous publication [6] indicated that the range for austenitising is; 1123 - $1223 \mathrm{~K}$ and for austempering to be; 500 - 723 $\mathrm{K}$. Special heat-treatments performed, in the present investigation. Austenitising and austempering temperatures, used in the present investigation, were carefully selected to be $1143 \mathrm{~K}$ and $1203 \mathrm{~K}$ for the first and $573 \mathrm{~K}$ and $673 \mathrm{~K}$ for the latter to fill the gap in literature. The ADI specimens were austenitised either at $1203 \mathrm{~K}$ or $1143 \mathrm{~K}$ for $3.6 \mathrm{ks}$ or $5.4 \mathrm{ks}$, respectively. While the LADI specimens were austenitised at $1143 \mathrm{~K}$ for $5.4 \mathrm{ks}$, in a muffle furnace with accuracy $\pm 5 \mathrm{~K}$, thereafter, transferred directly, for quenching into a salt bath containing Die Gusse As 140 at one of the austempering temperatures $673 \mathrm{~K}$ and $573 \mathrm{~K}$ for $3.6 \mathrm{ks}$ and $7.2 \mathrm{ks}$, respectively. After austempering, all specimens were air-cooled to $300 \mathrm{~K}$.

\subsubsection{Tempering}

Tempering treatment was performed on the as-cast LADI ingots at $873 \mathrm{~K}$ for $7.2 \mathrm{ks}$ to obtain the best combination of strength, hardness and machinability.

\subsection{Metallographic Characterisation}

The microstructural evaluations (including nodules and matrix characteristics) were conducted on small cubes, $20 \mathrm{~mm}$ side, taken from each Y-block of the as-cast and as-heat treated castings. Standard experimental techniques for metallography were used [11]. 3\% nital was used as an etchant for $8 \mathrm{~s}$ to reveal the structural characteristics of the investigated alloys. Observation of the microstructures was carried out using Reichert Me F2 universal optical microscope.

\subsection{Hardness Tests}

Micro- and macro-hardness tests were conducted. The latter type was conducted using three indentation hardness tests, 1) Vickers, 2) Brinell, and 3) Rockwell. All the hardness tests were carried out at ambient temperature (300 K) using Otto Wolpert-Weker universal hardness testing machine. Standard microhardness Vickers test was applied on the specimens of each type to obtain the hardness of its matrix constituents. It was also carried out on longitudinal section perpendicular to the worn surface at different distances. Wolpert high quality digital microhardness tester set at $200 \mathrm{~g}$ load for $15 \mathrm{~s}$ was used. Preparation of samples for microhardness tests was the same as those for microstructure.

\subsection{Tensile Test}

Tensile tests were performed in accordance with ASTM-E8-1990 and the round tensile specimens were used. The tensile tests were conducted on a motor driven tensiometer machine type $\mathrm{W}$ at ambient temperature (300 K) at a strain rate of $4 \times 10^{-4} \mathrm{~s}^{-1}$ up to fracture. Data collected included ultimate tensile strength $\left(\mathrm{R}_{\mathrm{m}}\right), 0.2 \%$ proof stress $\left(\mathrm{Rp}_{0.2}\right)$, percentage elongation $\left(\% \mathrm{~A}_{4}\right)$ and toughness. Each value was the average of at least three successful tensile tests. 


\subsection{Impact Test}

For Charpy impact tests, smooth (unnotched) specimens were used in accordance with ASTM-E23-1990. The capacities of Charpy impact testing machine type RKP300 were $300 \mathrm{~J}$. Impact tests were performed at $300 \mathrm{~K}$ and all impact test results were averaged from, at least, three successful tests.

\subsection{Wear Test}

Wear-resistance tests were carried out with a pin-on-ring type apparatus using the TNO-Tribometer under dry sliding conditions in the ambient air. ADI specimens in the form of cylindrical pin of $8 \mathrm{~mm}$ diameter and $12 \mathrm{~mm}$ height were used. The pin was pressed against the circumference of the ring under a constant load of $265 \mathrm{~N}$ for 2.7 ks duration at a constant sliding distance of $2500 \mathrm{~m}$. Mass losses were measured in grams before- and after wear tests with a precision to the fourth decimal by an analytical balance (Mettler). At least three successful tests were performed for each set of conditions and the average mass loss was calculated. After testing, the worn surfaces of pins were examined by optical microscope. Friction coefficient $(\mu)=F_{f} / F_{n}$ as $F_{n}=$ normal force, and $F_{f}=$ friction force was calculated.

\subsection{Fracture Characteristics}

Analysis of fracture surfaces illuminates the role of various microconstituents, and under different heat treatment conditions, in promoting or limiting tensile (static) and impact (dynamic) toughness. Caution was taken for appropriate handling of specimens after fracture, former to any fractographic examination. They were instantly examined, in the SEM, to avoid any accumulation of under humidity on the fracture surfaces. OM Axiovert 405 M-ZEISS was used to explain the fracture behaviour of the two types; tensile and impact fracture.

\section{Results and Discussion}

All kinds of tested-alloys together with their conditions are listed in Table 2.

\subsection{Microstructural Features}

Nodule characteristics: As polished specimen-photographs were examined for nodule-characteristics. The differences among the nodule characteristics (count, size and nodularity) were, therefore, detected. Figure 1(a), Figure 1(b) illustrates, the as-polished microstructure for alloy 1 (conventional DI) and 6 (as-cast LADI), resprectively. Higher nodule count $\left(87\right.$ nodule $\left./ \mathrm{mm}^{2}\right)$ and smaller nodule size $(50 \mu \mathrm{m})$ was observed in Figure 1 (a) for alloy 1 (DI) relative to that in Figure 1(b) $\left(69\right.$ nodule $/ \mathrm{mm}^{2}$ and nodule size $62 \mu \mathrm{m}$ ) for alloy 6 (LADI). Comparing the two types of alloys 1 and 6 with ADI and as-treated (LADI) specimens, respectively, it was observed that, there is no remarkable change in the graphite nodule characteristics due to austempering heat treatment. Therefore, alloys 1 and 6 were taken to represent the other types of ADI and LADI specimens, respectively. The value of \% nodularity of alloy 1; $95.5 \%$ and alloy $6 ; 93.5 \%$ are close to each other. These results can be attributed to the same SCR. These variations of nodule count may stem from the variation in chemical compositions between the two types of ductile-irons [9].

Also, Jenkins [12] stated that, nodule count affects graphite size and shape. Increasing nodule count results in a decrease in nodule size, which improves tensile and fracture properties. The present result of \% nodularity satisfies the ASM specification [13], which indicates that for most purposes, a \% nodularity of $85 \%-100 \%$ should be in a fully nodular form. Additionally, these results are confirmed with the results obtained by Grech [14]. He concluded that, the morphology of graphite influences the final properties of an ADI. Whereas, for optimum mechanical properties, the \% nodularity of the graphite in castings with a low nodule count should be as high as possible.

\subsection{Microstructural Features}

Figure 2(a) and Figure 2(b) illustrates the matrix micro-constituents after etching the specimens for as-castalloys 1 and 6, respectively. The micostructure in Figure 2(a) is a typical bull's eye type [11] with ferrite surrounding the graphite nodules. The microstructure delineates, generally, graphite nodules embedded in a ferriticpearlitic matrix (48\% pearlite). Figure 2(b) represents the microstructure of alloy 6 with Ni content 2.22 mass \%. 
Table 2. Designations used, in the present investigation, for the 3 types (DI, ADI, LADI) of ductile-iron.

Conventional
ductile-iron

Figure 1. Graphite nodules as observed for as-polished specimens (a) alloy 1 (conventional DI) and (b) alloy 6 (LADL). Optical microscope.

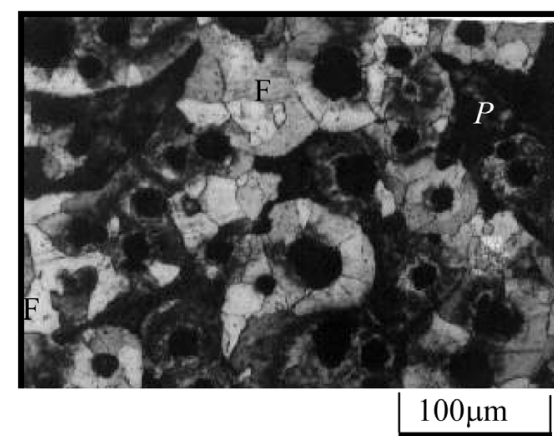

(a)

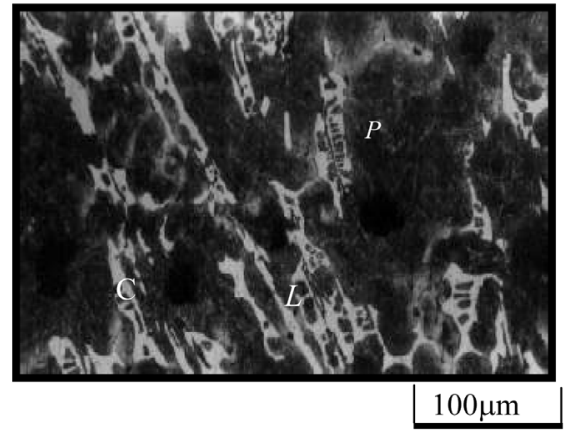

(b)

Figure 2. The observed matrix constituents for (a) alloy 1 (conventional DI), and (b) alloy 6 (as-cast LADI); after etching with nital $2 \%$. Optical microscope.

The matrix micro-constituents are mainly pearlite (P), ledeburite (L), and carbide (C) (cf. photo) occurring in the inter-nodular regions. Graphite nodules in a matrix of higher volume fraction of ferrite (52\%) provide a ductileiron with good ductility, impact resistance and tensile strength, as will be discussed later [15]. The microstructure of alloy 1 resembles those obtained previously by Fatahalla [15] and Jenkins [12]. The latter [12] indicated that, increasing nodule count decreases the pearlite content, decreasing strength and increasing elongation. The presence of carbide in the structure of alloy 6 (cf. Figure 2(b)) confirms the results of K. M. Ibrahim et al. [16] who suggested that the low Ni-alloy additions lead to the formation of intercellular carbides. The previous investigators [16] indicated that repetition of production of bainitic ductile-iron in the as-cast condition based on $\mathrm{Ni}$ and Mo could be achieved. While, for the present LADI, Mn and $\mathrm{Cr}$ were added in the as-cast condition. Moreover, there was slight difference in volume fraction $\left(V_{f}\right)$ of pearlite, which has a higher value than that of ledeburite and carbide in the matrix of alloy 6 .

This maybe imputed to the presence of elements that favour pearlite and carbides in the composition, such as $\mathrm{Mn}$ and Cr. Figure 3 reveal the matrix constituents of the ADI after etching for alloys 2, 3 (Figure 3(a), Figure 3(b)) and Figure 4 for alloys 5, 6. Using micro-hardness testing, and comparing the micro-constituents, ob- 
served in Figure 3 and Figure 4, with those in reference [11] it could be deduced that the grey regions are the bainite while the RA is the bright phase. Lower bainite structure is observed in Figure 3(a) and Figure 4(a) for austempering temperature of $573 \mathrm{~K}$, while upper bainite structure is observed in Figure 3(b) and Figure 4(b) for austempering temperature of $673 \mathrm{~K}$. Reducing austenitising temperatures from $1203 \mathrm{~K}$ to $1143 \mathrm{~K}$ will refine the bainitic structure, as observed comparing Figure 3 and Figure 4 respectively which confirms the previous explanation [6] [15]. The transformation of austenite into ferrite and carbon saturated austenite during austempering of ductile-iron occurs by nucleation and growth process [6] [17]. Consequently, the microstructure of ADI produced by austempering process is strongly dependent on the transformation temperature. Due to the slow rate of carbon diffusion at low austempering temperature, the growth rate of the ferritic platelets will be rather slow. Moreover, these ferrite platelets will be fine in nature and called then lower bainite [5] as is shown in Figure 3(a) and Figure 4(a). On the other hand, at higher austempering temperature, the carbon diffusion rate is higher and, consequently, the growth rate of these ferritic platelets is rather rapid. Consequently, these ferrite platelets will be large or coarse in nature and is called the upper bainite. Microhardness measurements and comparison with literature [17] revealed the different phases in the present investigation.

The matrix micro-constituents for alloys 7 and 8 (LADI) are shown in Figure 5(a) and Figure 5(b), respectively. Figure 5(a) revealed the phases being; fine LB, acicular ferrite (AF), and RA. However, in Figure 5(b) coarse UB replaced the fine LB and additionally, carbideis observed in small areas as indicated by " $C$ " in the lower-left region of Figure 5(b). Comparing Figure 5(a), Figure 5(b) for LADI with Figure 4(a), Figure 4(b) for ADI, it is noticed that acicular ferrite (AF) and carbide do exist in the latter (both are subjected to the same austenitising temperature of $1143 \mathrm{~K}$ and same austempering temperatures of $573 \mathrm{~K}$ for Figure 4(a) and Figure 5(a), and $673 \mathrm{~K}$ for Figure 4(b) and Figure 6(b). The present results shown in Figure 5 confirm that obtained previously by Bartosiewicz et al. [17] in which they observed coarse ferrite and, additionally, they revealed more austenite on the expense of ferrite at higher austempering temperature. Their conclusion is clearly noticed, in the present investigation, if we compare Figure 5(a) and Figure 5(b). It is also to be noticed that their austenitising temperature was $1130 \mathrm{~K}$ and their austempering temperatures were 533 and $658 \mathrm{~K}$ [17].

\subsection{Hardness Properties}

Macrohardness: Table 3 presents a macrohardness conversion table for the 3 types of ductile-iron measured by three hardness-indentation methods; Vicker's (HV), Brinell (HB) and Rockwell $\left(\mathrm{HR}_{\mathrm{A}}\right)$ and $\left(\mathrm{HR}_{\mathrm{C}}\right)$. The macrohardness values of ductile-iron investigated showed dependence on its matrix constituents. The lowest hardness is observed for alloy 1 (conventional DI) referring to ferritic-pearlitic matrix (cf. Figure 2(a)). This result can be explained since in the as-cast condition, the matrix would consist of varying proportions of pearlite and ferrite, and as the amount of pearlite increases, the macrohardness of the iron also increases [14]. Table 3 also, indicates a slight increase in hardness for ADI due to increasing the austenitising temperature from $1143 \mathrm{~K}$ (alloys 2, 3) to $1203 \mathrm{~K}$ (alloys 4, 5). The effect of austempering temperature is more pronounced in Table 3. Comparing the hardness of alloys 3, 5 with those of alloys 2, 4; a significant decrease is observed.

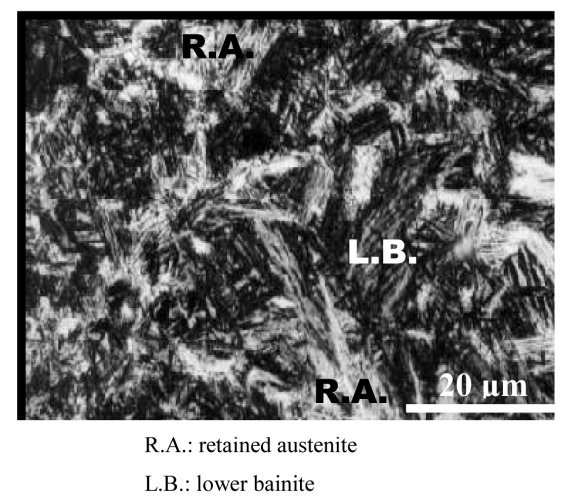

(a)

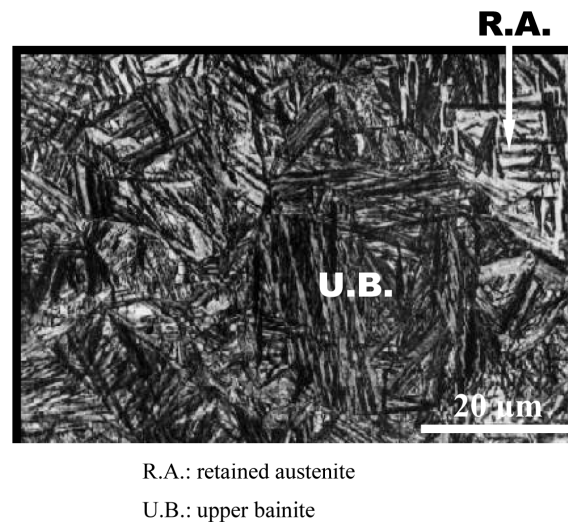

(b)

Figure 3. The observed matrix constituents for the ADI specimens after etching with nital $2 \%$. (a) alloy 2 and (b) alloy 3. Austenitised at $1143 \mathrm{~K}$ and austempered at (a) $573 \mathrm{~K}$, and (b) $673 \mathrm{~K}$. 


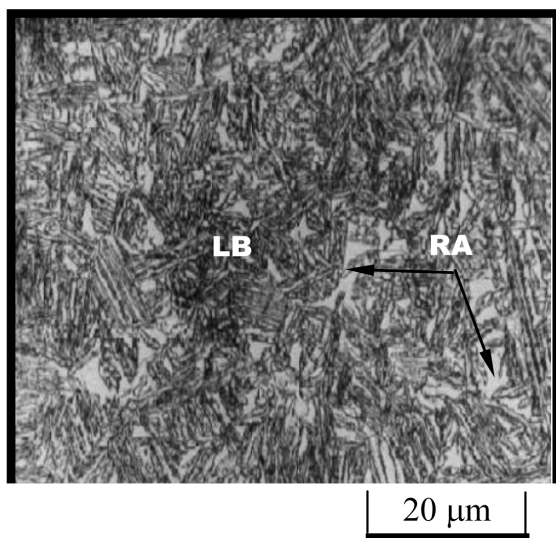

(a)

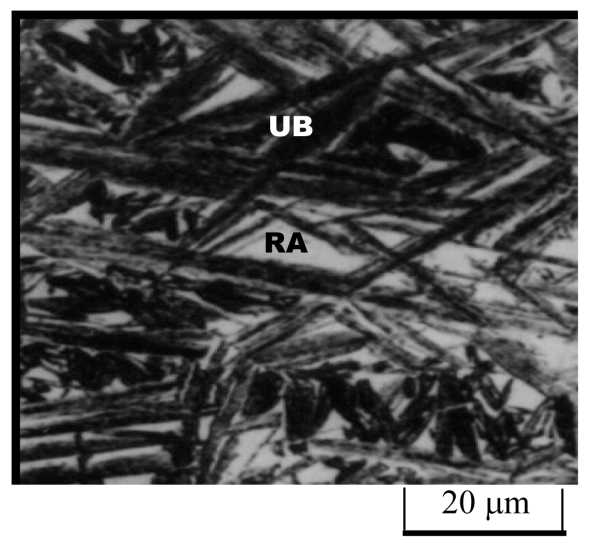

(b)

Figure 4. The observed matrix constituents for the ADI specimens after etching with nital $2 \%$. (a) alloy 4 and (b) alloy 5 . Austenitised at $1203 \mathrm{~K}$ and austempered at (a) $573 \mathrm{~K}$, and (b) $673 \mathrm{~K}$.

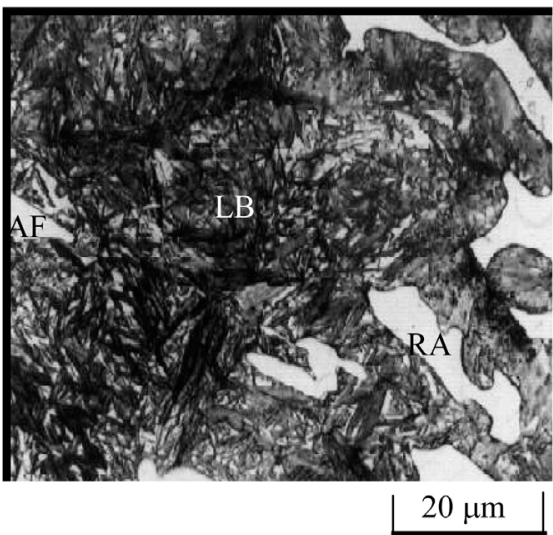

(a)

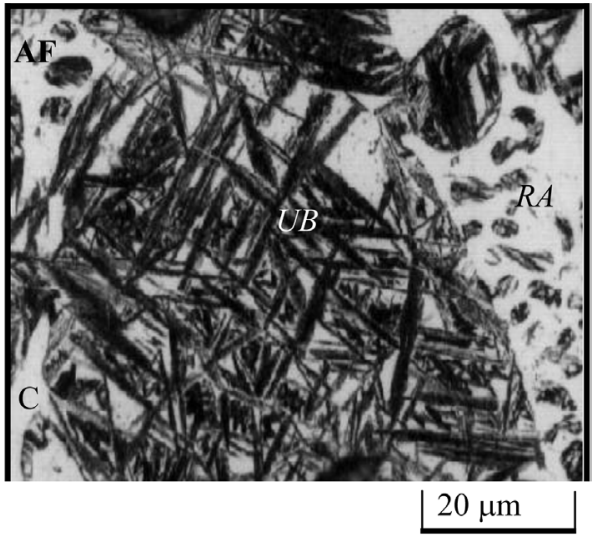

(b)

Figure 5. Matrix constituents of the LADI specimens after etching with nital (a) alloy 7 and (b) alloy 8. All specimens austenitised at $1143 \mathrm{~K}$ and austempered at (a) $573 \mathrm{~K}$, and (b) $673 \mathrm{~K}$.

Table 3. Hardness conversion table for the 3 types (DI, ADI, and LADI) of ductile-iron.

\begin{tabular}{ccccccccc}
\hline Iron type & DI & \multicolumn{9}{c}{ ADI } \\
$\begin{array}{c}\text { Hardness } \\
\text { Property }\end{array}$ & Alloy 1 & Alloy 2 & Alloy 3 & Alloy 4 & Alloy 5 & Alloy 6 & Alloy 7 & Alloy 8 \\
\hline HV (MPa) & 1850 & 4370 & 2910 & 4500 & 3100 & 4770 & 6130 & 4550 \\
HB (MPa) & 1780 & 4160 & 2870 & 4310 & 2920 & 4460 & 5600 & 4350 \\
HR $_{\mathrm{A}}$ & 51.3 & - & - & - & - & - & - & - \\
$\mathrm{HR}_{\mathrm{C}}$ & - & 43.0 & 26.4 & 44.6 & 27.3 & 45.6 & 56.0 & 45.0 \\
\hline
\end{tabular}

It is believed that the hardness of the UB observed in Figure 4(b) and Figure 5(b) together with the more amount of RA resulted in drastic decrease in hardness compared to Figure 4(a) and Figure 5(a). The fine structure of LB in Figure 4(a) and Figure 5(a) is believed to raise the hardness. The slight decrease in hardness for the LADI due to raising the austempering temperature refers to the increase in RA at $673 \mathrm{~K}$ relative to its amount at $573 \mathrm{~K}$ (cf. Figure 5(a), Figure 5(b)). The results of hardness, in the present investigation, confirms those obtained by Korichi Priestner [19] and Abouelala [20] with slight differences. It is to be taken into consideration that the slight differences in chemical composition, austenitising and austempering temperatures between the present and previous investigations are the cause of slight differences in results. Results in Table 3 for LADI 
specimens are supported by those obtained previously [21]. He indicated that the macrohardness values decrease with increasing the austempering temperatures. The lower hardness values are obtained at the austempering temperature of $673 \mathrm{~K}$. The higher hardness of the as-cast LADI given in Table 3 (4770 HV) refers to the microstructure of Figure 2(b) revealing hard pearlite and carbide constituents. This extremely high hardness value of as-cast LADI confirms the results obtained previously by Velez et al. [22]. The present results of hardness values for alloys 7 and 8 (LADI) show consistency with the results of Volkov et al. [23]. They suggested that by increasing austempering temperatures from $572 \mathrm{~K}$ to $663 \mathrm{~K}$, the Brinell hardness values decreased by about $16 \%$ to $20 \%$ on the average (This decrease per cent is $22 \%$ in the present investigation as detected from Table 3 ).

Microhardness: Table 4 lists the microhardness values of the different matrix micro-constituents for the 3 types of alloys under investigation. The hardness of the ferrite, and pearlite phases of alloy 1 confirmed the previous results [24] which showed values of 1700, $2900 \mathrm{MPa}$ for the ferrite and pearlite respectively. J. Aranzabal et al. [25] indicated that, the relative microhardness values range of common micro-constituents in cast iron are: Ferrite 1000 - $2500 \mathrm{MPa}$, austenite 1000 - $4000 \mathrm{MPa}$, acicular ferrite 3000 - $5000 \mathrm{MPa}$, austempered (Bainite) 2500 - $6000 \mathrm{MPa}$ and the carbide ranges from 10,000 to 20,000 MPa. The values of microhardness obtained in Table 4 for the different constituents fall within the indicated ranges of [25].

\subsection{Tensile Properties}

Table 5 shows the average values of ultimate tensile strength $\left(\mathrm{R}_{\mathrm{m}}\right), 0.2 \%$ proof stress $\left(\mathrm{R}_{\mathrm{p} 0.2}\right)$, maximum plastic strain $\left(\mathrm{A}_{4} \%\right)$ and toughness, which is calculated as the area under the tensile stress-strain diagram in MPa. Table 5 delineates that alloy 1 has the lowest $R_{m}$ and $R_{p 0.2}$; whereas, it exhibits highest $A_{4} \%$ and toughness " $E$ " compared to ADI and LADI alloys. This high toughness of alloy 1 may stem from the microplasticity associated with ferritic-pearlitic matrix and good \% nodularity [28]. One of the interesting results in the present investigation can be noticed from Table 5 being; comparable $\mathrm{R}_{\mathrm{m}}$, and $\mathrm{R}_{\mathrm{p}}$ of ADI (alloys 3, 5) to values of LADI (alloy 8). Moreover, alloys 3, 5 (ADI) showed superior ductility and toughness compared to those of LADI (alloy 8). Adding to the previous advantages the high hardness of alloys 3, 5 throws the light on possibility of using this relatively cheap ADI replacing the more expensive LADI in industrial applications such as producing rolling mills and others. Furthermore, the present tensile results confirm those obtained previously [11]-[13].

To evaluate the performance of the present alloys, the quality index (QI), which have been introduced by [12] implying both strength and elongation, is used:

$$
\text { (tensile strength } \mathrm{ksi})^{2} \times(\text { elongation } \%) / 1000=\mathrm{QI}
$$

where QI is a constant, and defined as Quality Index.

The calculated values of QI for the 3 types of ductile-iron are listed in Table 5. The highest values of QI is for alloy 3 (ADI); 119.9 and alloy 5 (ADI); 114.5 which, indicates a combination of higher strength and elongation and therefore, higher material performance. The segregation is known to reduce the toughness and ductility [6]. Table 5 which showed low ductility and toughness for the LADI suggests that the addition of alloying elements like $\mathrm{Ni}$ and $\mathrm{Mo}$ is not needed as far as the toughness is concerned.

\subsection{Impact Properties}

Table 6 shows the impact fracture toughness (energy absorbed in J) of the 3 types investigated of ductile-iron. The highest value is observed for the conventional DI (alloy 1) and the lowest values refer to LADI (alloys 6, 7, and 8). For the sake of comparison between the energy absorbed until fracture in a static test (tensile) and a dynamic test (impact) the values of toughness (area under stress strain diagram in MPa) was multiplied by the impact-test-volume to get the toughness in Joule units. The values listed in Table 6 indicate that the energy required to fracture the tensile specimen (static test) is higher than that obtained by the impact specimen (dynamic test) for the 3 types of ductile-iron. This decrease in energy through impact testing reflects the high rate of loading in impact test compared to tensile test. It is also interesting to point out that although the impact toughness of LADI (alloys 7, 8) was relatively very low, however, its toughness showed values 10 times or more the impact toughness (cf. Table 6).

This phenomenon reflects the sensitivity of these LADI alloys to strain rate testing [30]. The present results of energy absorbed for ADI specimens can be explained by that obtained by Ratto et al. [31]. They indicated that, in the low range of austempering temperatures ductile-iron develops moderate toughness and low impact 
Table 4. Microhardness values $\mathrm{HV}_{200}(\mathrm{MPa})$ for matrices of the constituents of the 3 types of ductile-iron.

\begin{tabular}{ccccccccc}
\hline $\begin{array}{c}\text { Iron type } \\
\text { Matrix } \\
\text { Constituents }\end{array}$ & \multicolumn{2}{c}{ DI } & \multicolumn{4}{c}{ ADI } & \multicolumn{3}{c}{ LADI } \\
\cline { 2 - 8 } Alloy 1 & Alloy 2 & Alloy 3 & Alloy 4 & Alloy 5 & Alloy 6 & Alloy 7 & Alloy 8 \\
\hline Ferrite (F) & 1715 & - & - & - & - & - & - & - \\
Pearlite (P) & 2775 & - & - & - & - & 3800 & 4000 & 3610 \\
Retained austenite (RA) & -- & 3560 & 3400 & 3670 & 3480 & -- & 3890 & 3765 \\
Acicular ferrite (AF) & -- & - & - & - & - & 3960 & 4430 & 3690 \\
Upper bainite (UB) & -- & - & 3775 & - & 3880 & -- & -- & 3950 \\
Lower bainite (LB) & -- & 4795 & - & 4920 & - & -- & 5380 & -- \\
Ledeburite (L) & -- & - & - & - & - & 6440 & 6710 & -- \\
Carbide (C) & -- & - & - & - & - & 8030 & 8820 & 7660 \\
\hline
\end{tabular}

Hardness units are MPa.

Table 5. Tensile properties and Quality Index of the 3 types of ductile-iron.

\begin{tabular}{cccccccccc}
\hline $\begin{array}{c}\text { Iron type } \\
\text { Tensile properties and } \\
\text { Quality Index (QI) }\end{array}$ & DI & Alloy 1 & Alloy 2 & Alloy 3 & Alloy 4 & Alloy 5 & Alloy 6 & Alloy 7 & Alloy 8 \\
\hline $\mathrm{R}_{\mathrm{m}}$ (MPa) & 518 & 961 & 844 & 980 & 890 & 998 & 1370 & 979 \\
$\mathrm{R}_{\mathrm{p} 0.2}$ (MPa) & 380 & 653 & 549 & 679 & 587 & 749 & 1092 & 666 \\
$\mathrm{~A}_{4}(\%)$ & 14.2 & 3.4 & 7.8 & 3.0 & 7.1 & 2.3 & 1.1 & 2.9 \\
Toughness* (MPa) & 57.4 & 20.6 & 48.9 & 17.4 & 47.2 & 14.1 & 9.5 & 16.7 \\
Quality Index(QI) & 77.8 & 63.8 & 119.9 & 58.8 & 114.5 & 47.0 & 42.3 & 56.8 \\
\hline
\end{tabular}

*Toughness is the area under the curve of the tensile stress-strain diagram (dimensions of the tensile test specimen: gauge diameter $=4 \mathrm{~mm}$, and gauge length $=20 \mathrm{~mm}$ ).

Table 6. Comparison between the values of impact energy and toughness (in energy units) along with the ratios between them for the 3 types of ductile-iron.

\begin{tabular}{ccccccccc}
\hline \multirow{2}{*}{$\begin{array}{c}\text { Iron type } \\
\text { property }\end{array}$} & DI & \multicolumn{9}{c}{ ADI } & \multicolumn{3}{c}{ LADI } \\
\cline { 2 - 9 } & Alloy 1 & Alloy 2 & Alloy 3 & Alloy 4 & Alloy 5 & Alloy 6 & Alloy 7 & Alloy 8 \\
\hline Eimpact $^{*}(\mathrm{~J})$ & 130.0 & 55.7 & 88.0 & 49.5 & 80.4 & 4.7 & 3.5 & 5.5 \\
$\mathrm{E}^{* *}(\mathrm{~J})$ & 160.0 & 70.4 & 127.6 & 60.5 & 114.4 & 48.4 & 33.0 & 55.0 \\
\hline
\end{tabular}

${ }^{*} \mathrm{E}$ impact $=$ Actual energy measured in impact test in $\mathrm{J} .{ }^{* *} \mathrm{E}=$ Area under tensile stress-strain diagram $(\mathrm{MPa}) \times$ volume of impact specimen $(0.010 \times 0.010 \times 0.055$ cubic metre $)(\mathrm{J})$.

strength. It is believed that, the low value of energy absorbed for alloy 6 (as cast LADI-cf. Table 6) referred to the effect of alloy additions; $\mathrm{Ni}, \mathrm{Mo}, \mathrm{Mn}$, and $\mathrm{Cr}$ and its segregation, and the presence of carbides. Kobayashi [27] concluded that, the increase in Mn content resulted in dropping of impact value, due to increasing of the $V_{f}$ of pearlite and segregation of Mn. Moreover, the carbides increase rapidly with increasing Mo addition, i.e.; the carbides and the segregation of Mo to cell boundaries cause significant loss of impact energy. Marrow and Çetinel [32] indicted that, the decline in impact toughness maybe due to the segregation of carbides around the ferrite/austenite grain boundaries as the austempering temperature exceeds $623 \mathrm{~K}$. Authors of [33] noted that, the impact energy values are more sensitive to these structural changes than, for example, \% elongation.

\subsection{Wear}

Wear characteristics: Table 7 lists the values of mass loss and coefficient of friction $(\mu)$ of the 3 types of iron; 
Table 7. Wear characteristics and hardness of the 3 types of ductile-iron.

\begin{tabular}{|c|c|c|c|c|c|c|c|c|}
\hline \multirow{2}{*}{$\begin{array}{c}\text { Iron type } \\
\text { Wear } \\
\text { Char. and macrohardness }\end{array}$} & \multirow{2}{*}{$\begin{array}{c}\text { DI } \\
\text { Alloy } 1\end{array}$} & \multicolumn{4}{|c|}{ ADI } & \multicolumn{3}{|c|}{ LADI } \\
\hline & & Alloy 2 & Alloy 3 & Alloy 4 & Alloy 5 & Alloy 6 & Alloy 7 & Alloy 8 \\
\hline Mass loss (mg) & 1491 & 168 & 614 & 151 & 579 & 63 & 22 & 97 \\
\hline Coefficient of friction $(\mu)$ & 0.48 & 0.28 & 0.31 & 0.27 & 0.30 & 0.24 & 0.21 & 0.26 \\
\hline HB (MPa) & 1780 & 4160 & 2870 & 4310 & 2920 & 4460 & 5600 & 4350 \\
\hline
\end{tabular}

DI, ADI, and LADI under investigation. Conventional DI (alloy 1) showed the highest value of mass loss and hence, the lowest wear resistance material. This may refer to the relatively high volume fraction of ferrite being 52\% (cf. Figure 2(a)) and in consistence with the suggestion given before by Ping et al. [33]. In general, reviewing the results in Table 7 we can observe inverse proportionality between the values of hardness and those for mass loss. This confirms that wear resistance is a hardness dependent property in consistence with results and conclusion of [34].

It can also be seen (cf. Table 7) that although the LADI (alloys 7, 8) showed the highest wear resistance, however, moderate wear resistance are observed for the ADI (alloys 2, 4). Therefore, LADI showed about twice higher values of wear resistance compared to ADI (alloys 2, 4), however, it is a compromise between required properties and alloy price. M. C. Jeng [34] stated that, the wear resistance absolutely depends on the hardness of the matrix structure, thus confirming the present results in Table 7. The coefficient of friction $(\mu)$ of alloy 1 is high because of the tendency to adhesion of soft ferrite matrix. The lower value of $\mu$ for ADI and LADI specimens maybe attributed to the difficulty of adhesion of the bainite matrix in ADI and hard carbide matrix in LADI. This phenomenon of decreasing " $\mu$ " is supported by Hemanth [35], who reported that, it should be possible to reduce $(\mu)$ by increasing the flow stress of the base metal by alloying or heat treatment.

Work-hardened layers due to wear: The work-hardened layers in the different alloys of the present investigation are seen in Figure 6. It is noticed that the higher the microhardness value the less thickness of the workhardened layer is observed. For instance, for the conventional DI-alloy 1-(lowest hardness) the thickness of the work-hardened layer is about $260 \mu \mathrm{m}$ while for the LADI-alloy 7-(highest hardness) the thickness is about 100 $\mu \mathrm{m}$. Other investigated alloys showed intermediate values of work-hardened layer thicknesses. It is also interesting to note that the work-hardened layer of the ADI (alloy 2) is more or less very similar in behaviour to that of the LADI (alloy 8) with a thickness of about $160 \mu \mathrm{m}$ for both. Again it is suggested that ADI with special heat treatments (austenitising and austempering) can be a material of industrial use.

\subsection{Fracture Surface Observations}

Fractographic study was carried out on selected-samples of the investigated alloys. For the sake of comparison alloys 2, 3 (ADI) and alloys 7, 8 (LADI) were selected for fractography since they were subjected to the same austenitising temperature of $1143 \mathrm{~K}$ and the same austempering temperatures (573, $673 \mathrm{~K})$. Additionally, the ascast DI (alloy 1) and as-cast LADI (alloy 6) fracture surfaces were investigated.

Failure in tension: Scanning electron microscopy was used to reveal the fracture surfaces for all investigated alloys (from Figure 7 to Figure 10). Figure 7 reveals the features of the fracture surface of the conventional DI (alloy 1). The ferrite areas, in the interior of the matrix, showed ductile patterns (symbol "F"). Sometimes small areas of dendritic lobes are also seen on the fracture surface (symbol "DL"). The graphite-nodules are pulled out leaving behind a vacant (symbol "V"). Graphite nodules (symbol "G") are observed in their sites surrounded by ferrite. It is interesting to note that there is an observable clearance between the nodules and the surrounding ferrite (symbol "C"). This clearance " $\mathrm{C}$ " reflects the amount of plastic deformation that occurred prior to fracture. The cavities were generated due to decohesion occurred at graphite/ferrite interface at very low strain level due to the fact that the graphite nodules are weakly bonded to the ferrite matrix surrounding them [36].

Figure 8 reveals the fractographs of ADI type (alloys 2, 3). Figure 8(a) shows cleavage pattern in the brittle area indicated, and small clearance " $\mathrm{C}$ " between the graphite-nodule and its cavity. These features reflect the relatively brittle mode of failure. Again vacant sites are seen "V".

Small area of ductile features can be seen in the Figure 8(a) occurring in the RA regions. The phenomenon of white small particles on the surface of graphite nodules in DI was related to carbon precipitation during heat 


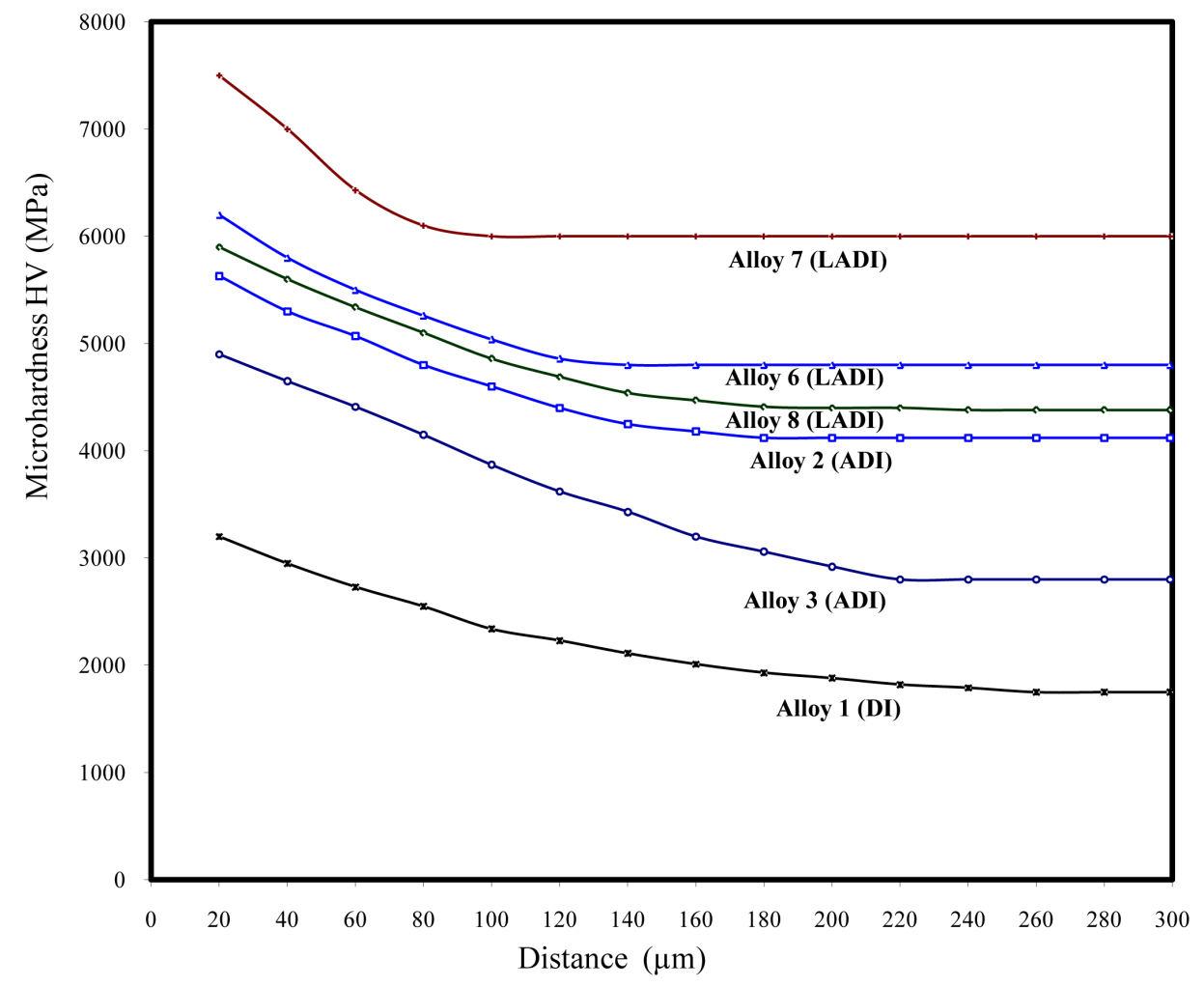

Figure 6. Variation of microhardness with distance from worn-surface revealing the thicknesses of the work-hardened layers for the 3 types of alloys under investigation (DI, ADI, and LADI).

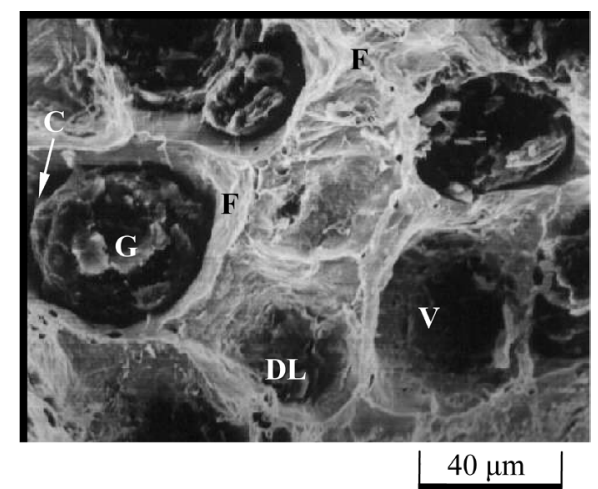

Figure 7. SEM-fracture surface of as-cast conventional DI (alloy 1) after failure in tension.

treatment as was indicated by N. Fatahalla et al. [37]. The white precipitates on graphite nodules shown in Figure 8(b) are due to the excess carbon of retained austenite in the matrix. The change of lower bainite to upper bainite due to raising the austempering temperature from $573 \mathrm{~K}$ to $673 \mathrm{~K}$ was reflected on the fracture characteristics in Figure 8(b) (alloy 3) relative to that observed in Figure 8(a) (alloy 2). Since the amount of RA was increased and, additionally, the ductility of upper bainite is higher than that of lower bainite, the ductile mode of fracture covered much larger areas on the fracture surface in Figure 8(b) relative to Figure 8(a). Brittle patterns areas are less than that in Figure 8(a) and it is to be noted that dimples can clearly be seen at the RA area neighbouring to nodule (cf. Figure 8(b)) reflecting moderate ductile mode of fracture in consistance with literature [38].

Figure 9(a), Figure 9(b) reveals the fractography of the LADI (alloys 7, 8). Both photos indicate a brittle mode of fracture. However, the clearance between the graphite-nodule and its corresponding cavity is much smaller in Figure 9(a) (alloy 7) relative to that of Figure 9(b) (alloy 8). This corresponds to the higher hardness 


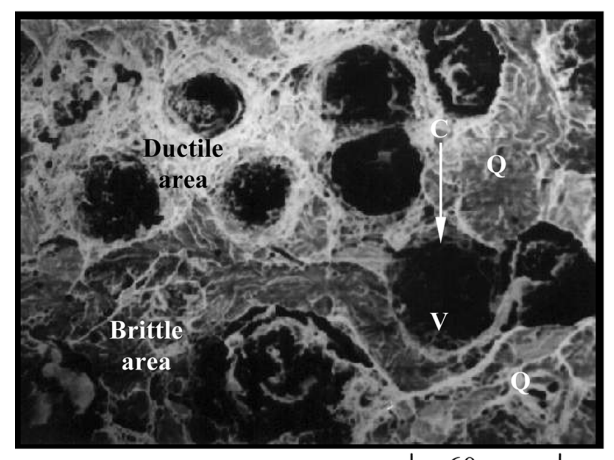

$60 \mu \mathrm{m}$

(a)

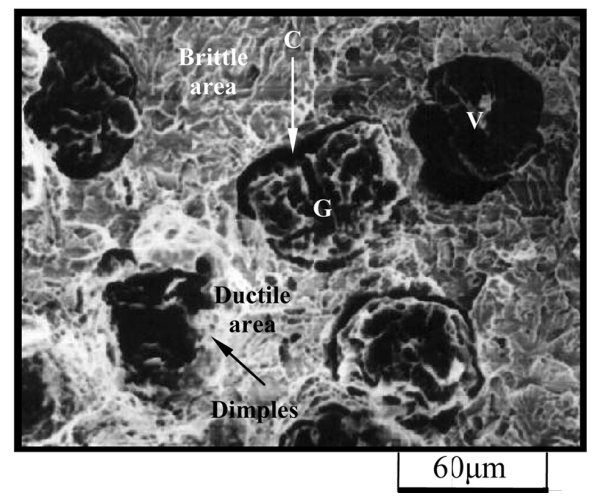

(b)

Figure 8. SEM-Fracture surfaces of the type ADI austenitised at $1143 \mathrm{~K}$ and austempered at (a) $573 \mathrm{~K}$-alloy 2-, (b) $673 \mathrm{~K}$-alloy 3-.

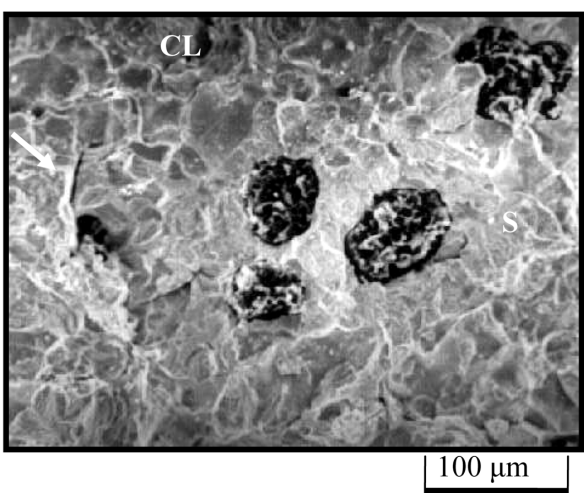

(a)

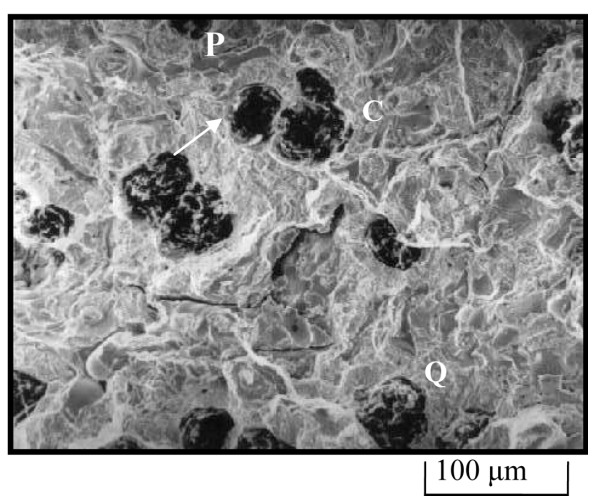

(b)

Figure 9. SEM-Fracture surfaces of LADI austenitised at $1143 \mathrm{~K}$, and austempered at (a) $573 \mathrm{~K}$ -alloy 7-, and (b) $673 \mathrm{~K}$-alloy 8-after failure in tension.

and strength of alloy 7 relative to that of alloy 8. Features in Figure 9(a) reveal cleavage pattern and faceted regions (symbol "S") indicating a brittle mode of fracture. In Figure 9(b) the features showed quasi-cleavage and pearlitic areas, and the clearance was relatively wider than that for alloy 7 . The relatively larger amount of RA and the more ductile upper bainite do affect the fracture pattern. The effect of some alloying elements on the fracture behaviour of DI was previously investigated [39] supporting the present results.

Figure 10 shows the fracture surface of the as-cast LADI (alloy 6). Fragmentation of graphite can be observed, large areas of quasi-cleavage "Q" and facetted pattern "S", and pearlite regions "P". Very tight clearance "C" (indicated by a white arrow) between graphite-nodules and its corresponding cavities reflecting the brittleness of the alloy.

Failure in impact: Figure 11 shows the fracture surface of the conventional as-cast DI (alloy 1) after failure in impact testing (high rate of loading). The surface features still resemble a ductile mode of fracture. Smooth ripple pattern surrounding the graphite nodules in the ferrite regions is observed (cf. Figure 11). Additionally, areas of dimples are also shown in the figure. Again we can observe vacant sites "V" referring to pulled nodules and some fragmentation of graphite. The relatively large clearance between nodule and its cavity indicates the degree of plasticity prior to fracture, this result confirms that obtained previously by Fatahalla et al. [40].

Figure 12 shows the fracture surfaces of ADI (alloys 2, 3) after failure in impact testing. Both photos reveal a mixed mode of fracture (ductile + brittle). However, in Figure 12(a), cleavage "CL" pattern is revealed in the upper portion (brittle characteristic) while smooth ripple pattern " $\mathrm{R}$ " is seen in the lower area of the same photo (ductile feature). In Figure 12(b) most of the fracture surface is characterised by a smooth ripple pattern " $\mathrm{R}$ " plus regions of dimples " $\mathrm{D}$ " reflecting higher ductility. The clearance " $\mathrm{C}$ " between the nodules and their corresponding cavities are much tolerated in Figure 12(b) rather than that observed in Figure 12(a), reflecting plastic- 


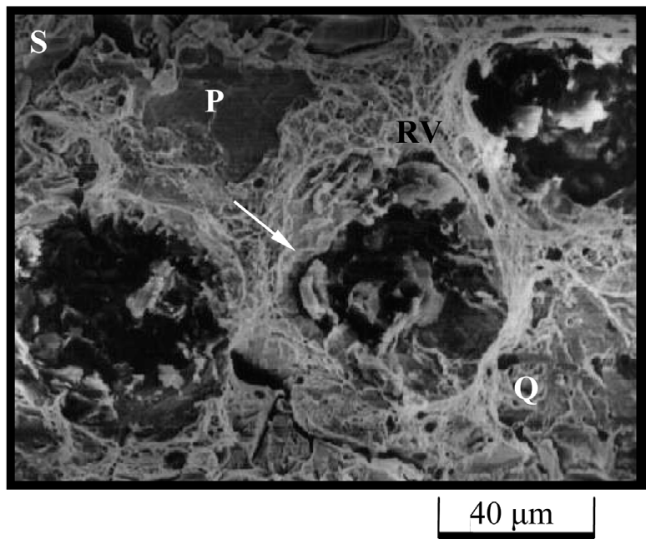

Figure 10. SEM-Fracture surface of as-cast LADI (alloy 6) after failure in tension.

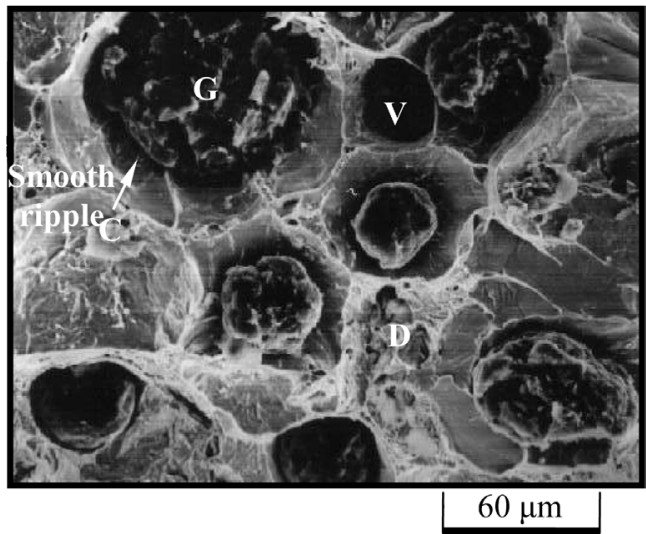

Figure 11. SEM-Fracture surface of as-cast DI (alloy 1) after failure in impact.

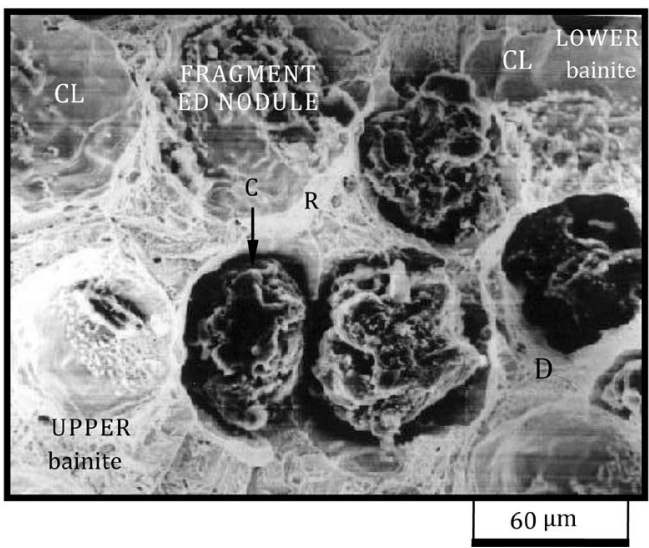

(a)

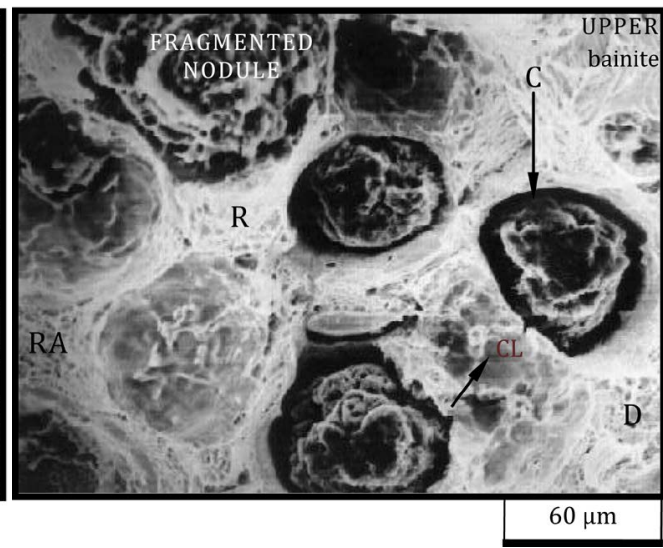

(b)

Figure 12. SEM-Fracture surfaces of ADI type austenitised at $1143 \mathrm{~K}$ and austempered at (a) $573 \mathrm{~K}$ -alloy 2-, and (b) $673 \mathrm{~K}$-alloy 3-after failure in impact.

ity and higher ductility in the latter. Fragmented graphite nodules are observed in both photos of Figure 12. Wolkov et al. [41] examined the behaviour of ADI under dynamic load in terms of the fracture mechanics. They found that, as "brittleness" is considered in terms of energy, they ought to classify high strength bainitic ductileirons as brittle fracture materials.

Figure 13 shows the fracture surfaces of LADI (alloys 7, 8) fractured in impact. All features in both photos of Figure 13 reveal tendency to brittleness. However, Figure 13(b) reveals a bit of ductile fracture features such as 
ripple " $\mathrm{R}$ " and dimple "D" patterns in the ductile features region of Figure 13(b). Although a small area in Figure 13(a) (alloy 7) showed dimple pattern, however, most of the fracture surface is covered with cleavage "CL", carbide "S", and hard lower bainite regions. On the other hand, facets and carbide areas were also detected in Figure 13(b). The effect of high strain rate loading (impact) on the fracture phenomenon of LADI (alloys 7, 8) can be clearly seen if we compare the photos in Figure 13 with those in Figure 9 (tension).

Figure 14 shows the fracture surface of the as-cast LADI (alloy 6) after failure in an impact test. The river pattern "RV" of ausferrite in between two graphite nodules, can be seen. Also, quasi-cleavage features "Q" that occur on unspecified planes of pearlite and the flat facets " $\mathrm{S}$ " of carbide indicate the brittleness of the alloy. Tightness between the nodules and their corresponding cavities, i.e. small clearance "C" is another evidence of less plastic deformation prior to fracture. Alloy 6 (LADI) has better tensile strengths, macrohardness and lower impact energy than that of alloy 1 which refers to the blocky carbides located around the graphite nodules in the former. Brittleness and low toughness of alloy 6 (LADI) is believed to refer to segregation of the alloying elements; $\mathrm{Ni}, \mathrm{Mn}, \mathrm{Mo}$, and $\mathrm{Cr}$ and formation of carbides that occurred in the matrix.

\section{Conclusions}

1) Successful production of conventional ductile iron (DI), austempered DI, and low-alloyed DI was under the same experimental conditions.

2) Microstructures of all types of DI (8 groups of specimens) were revealed, therefore, investigated for different constituents and correlated with chemical compositions.

3) A hardness conversion table was introduced implying Brinnel, Vicker's, and Rockwell hardness for the investigated 3 types of ductile iron.

4) The microhardness values for different microconstituents were determined. Microhardness profile was drawn with distance from worn surface to detect the work-hardened layer thicknesses.

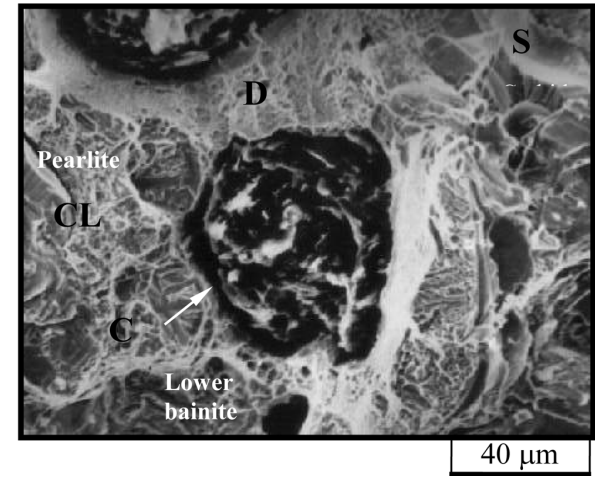

(a)

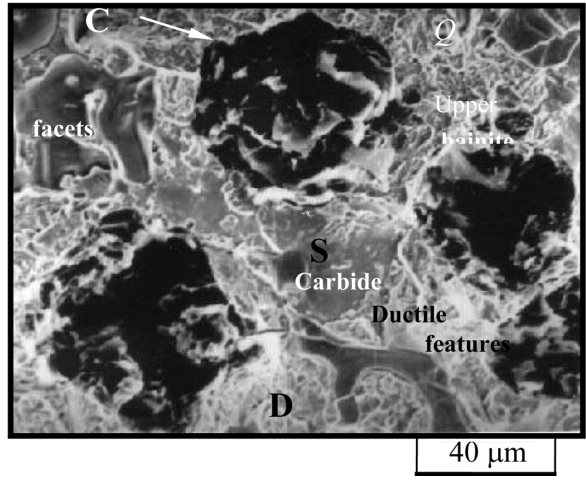

(b)

Figure 13. SEM-Fracture surfaces of LADI austenitised at $1143 \mathrm{~K}$ and austempered at (a) 573 K-alloy 7-, (b) 673 K-alloy 8-after failure in an impact test.

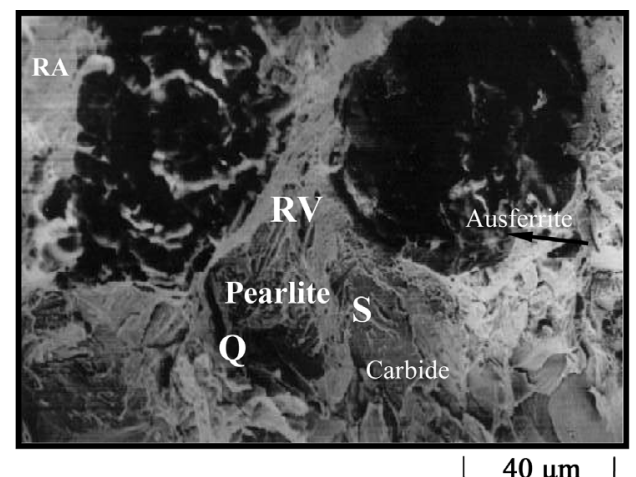

Figure 14. SEM-Fracture surface of as-cast LADI (alloy 6) after failure in impact. 
5) Tensile properties (ultimate, proof, elongation \%, and toughness) were determined for all investigated types of ductile-iron.

6) Impact toughness was measured for all alloys under investigation, and these values were compared with toughness values obtained from stress-strain diagrams. Thus the effect of strain rate loading on toughness was investigated.

7) Some wear characteristics were investigated implying weight loss and coefficient of friction for all alloys.

8) Fracture surface observation was conducted using the SEM to reveal the mode of fracture and features of the surface. Correlation of fracture phenomena with other obtained results was introduced.

9) The suitable properties of the ADI alloys, specially heat-treated, compared to that of the LADI, suggested the possibility of using the cheap former alloys replacing the expensive latter type to produce, for instance, rolling mills and other industrial products.

\section{References}

[1] Zhukov, A.A., Basak, A. and Yanchenko, A.B. (1997) New Viewpoints and Technologies in Field of Austempering of Fe-C Alloys. Materials Science and Technology, 13, 401-407. http://dx.doi.org/10.1179/mst.1997.13.5.401

[2] Nofal, A. and Jekova, L. (2009) Journal of the University of Chemical Technology and Metallurgy, 44, 213-228.

[3] Prado, J.M., et al. (1995) Materials Science and Technology, 11, 294-298.

[4] Basso, A., et al. (2010) Experimental and Numerical Assessment of Fracture Toughness of Dual-Phase Austempered Ductile Iron. Fatigue \& Fracture of Engineering Materials \& Structures, 33, 1-11.

[5] Basso, A., et al. (2010) Mechanical Characterization of Dual Phase Austempered Ductile Iron. ISIJ International, 50, 302-306. http://dx.doi.org/10.2355/isijinternational.50.302

[6] Stokes, B., Gao, N. and Reed, P.A.S. (2007) Effects of Graphite Nodules on Crack Growth Behaviour of Austempered Ductile Iron. Materials Science and Engineering A, 445-446, 373-385. http://dx.doi.org/10.1016/j.msea.2006.09.058

[7] Kocatepe, K., Cerah, M. and Erdogan, M. (2007) Journal of Materials Processing Technology, 28, 172- 181.

[8] Fatahalla, N., AbuElEzz, A. and Semeida, M. (2009) C, Si and Ni as Alloying Elements to Vary Carbon Equivalent of Austenitic Ductile Cast Iron: Microstructure and Mechanical Properties. Materials Science and Engineering A, 504, 81-89. http://dx.doi.org/10.1016/j.msea.2008.10.019

[9] Kovacs, B.V. (1994) Alloying Elements and Heat Treatment of ADI. $2^{\text {nd }}$ International ADI Seminar, Helsinki University of Technology, 1-3 June 1994, 1-12.

[10] Fatahalla, N., Bahi, S. and Hussein, O. (1996) Metallurgical Parameters, Mechanical Properties and Machinability of Ductile Cast Iron. Journal of Materials Science, 31, 5765-5772. http://dx.doi.org/10.1007/BF01160826

[11] American Society for Metals (2005) Metals Handbook, Properties and Selection: Iron and Steel. Metals Park.

[12] Jenkins, L. (1990) Ductile Iron Data for Design Engineers. QIT-Feret Titane Inc., Sorel, Canada.

[13] Smithells, C.J. (1992) Metals Reference Book. 7th Edition, Butterworth-Heinemann Ltd., Oxford.

[14] Grech, M. (1993) An Update on Austempered Ductile Cast Iron. Proceedings of the International Conference on Mechanical Behaviour of Ductile Cast Iron and Other Cast Metals, Kitakyushu, 30 July-1 August 1993, 319-326.

[15] Hussein, O. and Fatahalla, N. (1994) Machinability of Ductile Cast Iron Types. Master's Thesis, Faculty of Engineering, Al Azhar University, Cairo.

[16] Ibrahim, K.M., Nofal, A.A. and Ibrahim, M.M. (2008) Effect of Alloying Additions and Two-Step Austmpering on the Microstructure and Mechanical Properties of Ductile Iron. Proceedings of the 9th International Conference on $\mathrm{Me}$ chanical Design and Production (MDP-9), Cairo, 8-10 January 2008.

[17] Bartosiewicz, L., Singh, I., Alberts, F.A., Krause, A.R. and Putatunda, S.K. (1995) The Influence of Chromium on Mechanical Properties of Austempered Ductile Cast Iron. Journal of Materials Engineering and Performance, 4, 90101. http://dx.doi.org/10.1007/BF02682710

[18] Putatunda, S.K., Kesani, S., Tackett, R. and Lawes, G. (2006) Development of Austenite Free ADI (Austempered Ductile Cast Iron). Materials Science and Engineering: A, 435-436, 112. http://dx.doi.org/10.1016/j.msea.2006.07.051

[19] Korichi, S. and Priestner, R. (1995) High Temperature Decomposition of Austempered Microstructures in Spheroidal Graphite Cast Iron. Materials Science and Technology, 11, 901-907. http://dx.doi.org/10.1179/mst.1995.11.9.901

[20] Cox, G.J. (1974) Foundry Trade Journal, 134, 741-749.

[21] Abouelela, K.M.I. (2000) Effect of Molybdenum and Nickel Additions on Microstructure and Mechanical Properties of As-Cast and Austempered Ductile Cast Iron. Doctoral Dissertation, Technical University of Berlin, Berlin.

[22] Velez, J.M., Garboggini, A. and Tschiptschin, A.P. (1996) Effect of Silicon on Kinetics of Bainitic Reaction in Aus- 
tempered Ductile Cast Iron. Materials Science and Technology, 12, 329-337. http://dx.doi.org/10.1179/mst.1996.12.4.329

[23] Volkov, K.G., et al. (1993) Silicon and Heat Treatment Parameters Effects on Austempering Ductile Iron Structure and Mechanical Properties. Proceedings of the 34th Mechanical Working and Steel Processing Conference, Montreal, 2528 October 1993, 341-349.

[24] Labrecque, C. and Gagné, M. (1998) Review Ductile Iron: Fifty Years of Continuous Development. Canadian Metallurgical Quarterly, 37, 343-378.

[25] Kapturkiewicz, W., Fraś, E., Lelito, J. and Burbelko, A.A. (2006) Measurement of the Kinetics of Thermal Effects during Phase Transformations in ADI. Journal of Materials Science Forum, 508, 585-590. http://dx.doi.org/10.4028/www.scientific.net/MSF.508.585

[26] Aranzabal, J., Gutierrez, I., Rodriguez-Ibabe, J.M. and Urcola, J.J. (1997) Influence of the Amount and Morphology of Retained Austenite on the Mechanical Properties of an Austempered Ductile Iron. Metallurgical and Materials Transactions A, 28, 1143-1156. http://dx.doi.org/10.1007/s11661-997-0280-6

[27] Osafune, Y. and Yuyama, M. (2008) Microstructure and Properties of Austempered Ductile Cast Iron with Refined Graphite Nodules. International Journal of Cast Metals Research, 21, 90-95.

[28] Kobayashi, T. (2004) Ductile Cast Iron. In: Kobayashi, T., Ed., Strength and Toughness of Materials, Springer, Tokyo, 89-110. http://dx.doi.org/10.1007/978-4-431-53973-5_5

[29] Kobayashi, T. and Yamamoto, S. (1996) Effect of Holding Time in the $(\alpha+\gamma)$ Temperature Range on Toughness of Specially Austempered Ductile Iron. Metallurgical and Materials Transactions A, 27, 1961-1971.

[30] Ravishankar, K.S., Rao, P.P. and Udupa, K.R. (2010) Improvement in Fracture Toughness of Austempered Ductile Iron by Two-Step Austempering Process. International Journal of Cast Metals Research, 23, 330-343.

[31] Ratto, P.J.J., Ansaldi, A.F. and Fierro, V.E. (2001) Low Temperature Impact Tests in Austempered Ductile Iron and Other Spheroidal Graphite Cast Iron Structures. ISIJ International, 41, 372-380. http://dx.doi.org/10.2355/isijinternational.41.372

[32] Marrow, T.J., Cetinel, H., Al-Zalmah, M., Macdonald, S., Withers, P.J. and Walton, J. (2002) Fatigue Crack Nuclei in Austempered Ductile Cast Iron. Fatigue \& Fracture of Engineering Materials \& Structures, 25, 635-648.

[33] Ravishankar, K.S., Udupa, K.R. and Rao, P.P. (2008) Development of Austempered Ductile Iron for High Tensile and Fracture Toughness by Two Step Austempering Process. Proceedings of the 68th World Foundry Congress, Chennai, 7-10 February 2008, 35-40.

[34] Jeng, M.C. (1993) Abrasive Wear Study of Bainitic Nodular Cast Iron. Journal of Materials Science, 28, 6555-6561. http://dx.doi.org/10.1007/BF00356393

[35] Hemanth, J. (2000) Wear Characteristics of Austempered Chilled Ductile Iron. Materials and Design, 21, 139-148. http://dx.doi.org/10.1016/S0261-3069(99)00101-6

[36] Gagne, M., et al. (2006) Transactions of the American Fisheries Society, 114, 615-626.

[37] Gomma, T. and Fatahalla, N. (1996) Effect of Structure on Properties of Ductile Cast Iron. Ph.D. Thesis, Al Azhar University, Cairo.

[38] Dorazil, E. (1991) High Strength Austempered Ductile Cast Iron. Ellis Horwood Ltd. and Academia, England.

[39] Edere, T.C. (2011) Tensile Properties of Austempered Ductile Iron. Proceedings of the 14th International Esaform Conference on Material Forming, Belfast, 27-29 April 2011.

[40] Refaey, A. and Fatahalla, N. (2003) Effect of Microstructure on Properties of ADI and Low Alloyed Ductile Iron. Journal of Materials Science, 38, 351-362. http://dx.doi.org/10.1023/A:1021177902596

[41] Wolkov, K., et al. (1990) Austempered Ductile Iron under Dynamic Load. Proceedings of the 57th World Foundry Congress, Osaka, 23-28 September 1990, 8-2-8-7. 
Scientific Research Publishing (SCIRP) is one of the largest Open Access journal publishers. It is currently publishing more than 200 open access, online, peer-reviewed journals covering a wide range of academic disciplines. SCIRP serves the worldwide academic communities and contributes to the progress and application of science with its publication.

Other selected journals from SCIRP are listed as below. Submit your manuscript to us via either submit@scirp.org or Online Submission Portal.
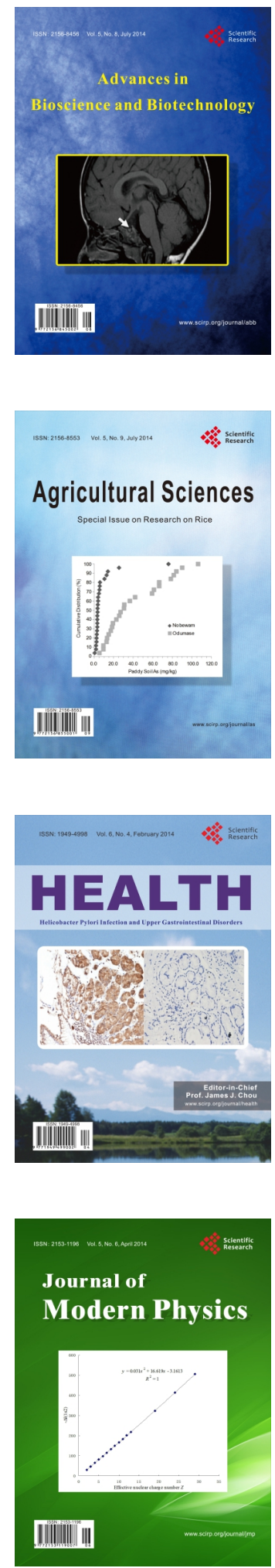
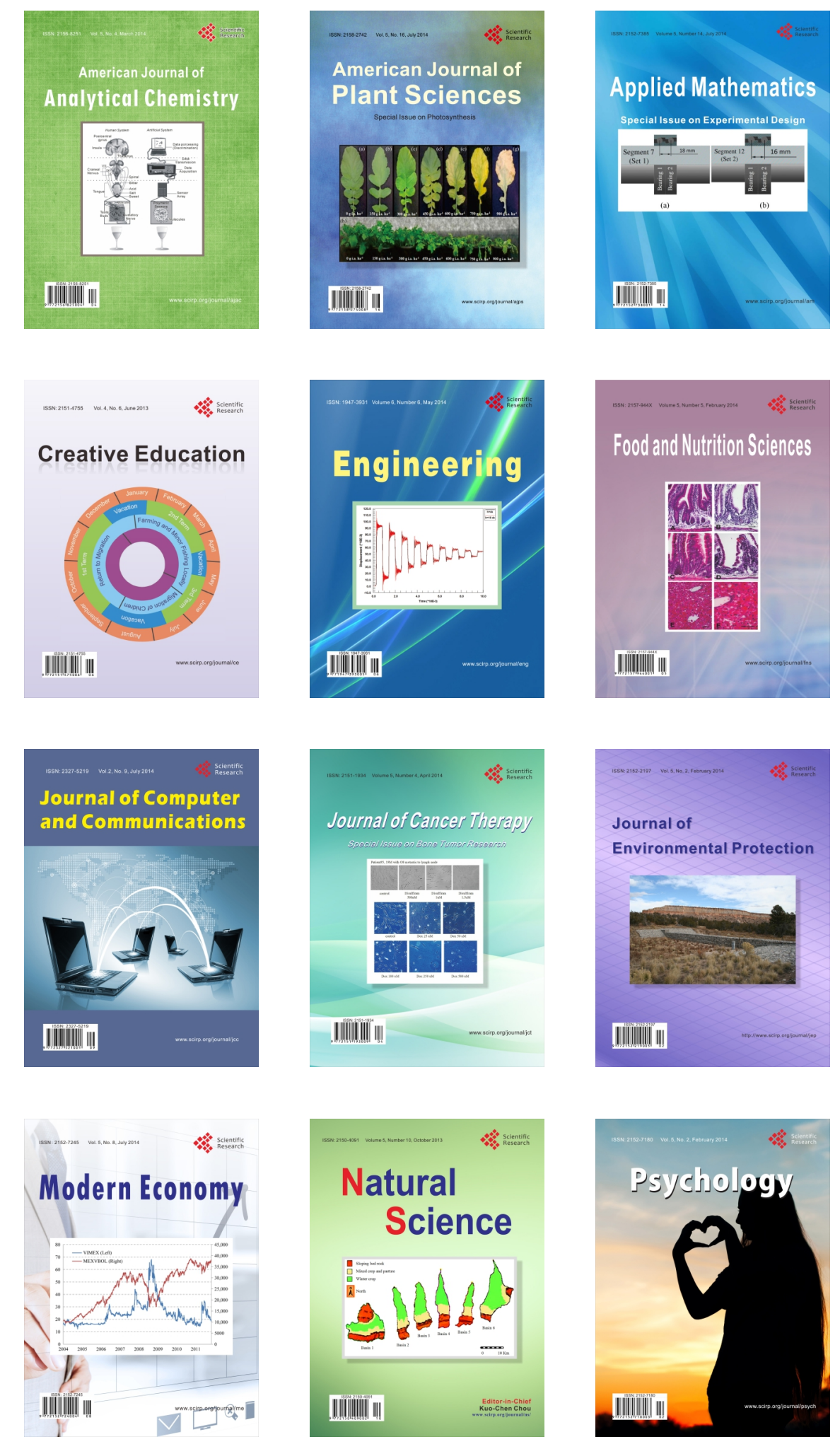